\title{
EDUCAÇÃO MORAL HOJE: CENÁRIOS, PERSPECTIVAS E PERPLEXIDADES
}

\author{
Pedro Goergen*
}

A justiça não é uma parte da excelência moral, mas a moral inteira. (Aristóteles)

\begin{abstract}
RESUMO: Partindo da constatação de que a moral é um dos mais discutidos e polêmicos temas da sociedade contemporânea, o autor observa uma relação entre a visibilidade do debate moral e a gravidade das práticas imorais. Na tentativa de encontrar caminhos que conduzam à mudança dessa realidade, desenvolve o argumento de que os problemas morais não se restringem apenas ao comportamento desse ou daquele grupo social, desse ou daquele indivíduo, mas que eles se encontram intrinsecamente relacionados às tradiçôes, aos costumes e aos valores que constituem o ethos histórico-cultural da sociedade. Por isso, entende que a superação da barbárie moral não pode ser alcançada mediante intervenções e sançōes tópicas, locais, superficiais, mas que é necessário um repensar amplo e corajoso dos arquétipos de nossa cultura no que se refere aos conceitos de cidadania, democracia, justiça social e espaço público. $\mathrm{O}$ autor defende a tese de que a educação moral, para além da tradicional disciplinarização, deve centrar-se na formação dialógica do sujeito moral, tendo como escopo a virtude da justiça.
\end{abstract}

Palavras-chave: Educação moral. Formação de professores. Justiça social.

\section{MORAL EDUCATION NOWADAYS: SCENARIOS, PERSPECTIVES AND PERPLEXITIES}

ABSTRACT: From the statement of fact that moral is one of the most discussed and polemical topics in our contemporaneous society, the author observes a relationship between the visibility of the

Doutor em Filosofia, professor titular da Universidade de Sorocaba (UNISO) e professor titular (aposentado) da Universidade Estadual de Campinas (UNICAMP). E-mail: goergen@unicamp.br

Educ. Soc., Campinas, vol. 28, n. 100 - Especial, p. 737-762, out. 2007 
moral debate and the seriousness of immoral practices. In an attempt to find paths that lead to change this reality, he develops the argument that the moral problems are not restricted to the behavior this or that social group or individual, but that they are intrinsically related to the traditions, customs and values that constitute the historical-cultural ethos of society. He thus understands that moral barbarism cannot be overcome through interventions and topical, local or superficial sanctions, but that we need rethinking widely and courageously the archetypes of our culture in what regards the concepts of citizenship, democracy, social justice and public space. The author advocates the thesis that, beyond the traditional disciplinarization, moral education must focus on the dialogical training of the subject's moral, with the virtue of justice in our scope.

Key words: Education moral. Traininglformation of teachers. Social justice.

\section{Introdução}

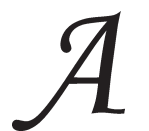

moralidade da sociedade contemporânea assume hoje uma dimensão inversamente proporcional à sua visibilidade discursiva. Parece que quanto mais se fala em ética e moral, mais escandalosamente imorais se tornam as práticas. O discurso moralizante nasce, de um lado, da justa revolta das vítimas da barbárie moral e, de outro, do cinismo dos protagonistas da imoralidade. Comum aos dois aportes é a tendência de culpabilizar os outros, sejam eles indivíduos, grupos ou instituições. No presente trabalho, quero defender o ponto de vista de que a barbárie moral que vivemos não se explica nem se soluciona culpando o outro e exigindo que ele mude seu comportamento. As raízes da imoralidade são muito mais profundas e alcançam o terreno comum da tradição e da cultura. Por isso, entendo que a superação da barbárie moral não pode ser alcançada mediante intervenções e sanções tópicas, locais, superficiais, mas que é necessário um repensar amplo e corajoso dos arquétipos de nossa cultura, no que se refere aos conceitos de cidadania, democracia, justiça social e espaço público. Tal projeto deve relacionar a nossa tradição cultural e os valores a ela inerentes com o contexto moralmente perverso do modo de produção capitalista neoliberal que nos governa no momento. As perplexidades e ambivalências ético-morais precisam ser entendidas e analisadas a partir da confluência das características e tradições de nossa 
cultura com o modo de produção e os referenciais e representações ético-morais que lhe são próprias. Estes dois aportes - a tradição cultural e a realidade econômico-política - representam as vertentes cínicas das quais nasce a imoralidade que barbariza nossas relações sociais. Imoralidade essa que ora gera revolta, ora não provoca mais que indiferença e conformismo.

Essa leitura da ética e da moral nos permite concluir que o discurso moralizante, que acredita num projeto de moralização social mediante a repressão, apenas atinge a face aparente e superficial de um fenômeno cuja matriz é antes estrutural, em termos histórico-culturais e econômico-políticos. Essa constatação, por sua vez, nos faculta perceber que a transformação moral, considerada uma das grandes urgências da sociedade atual, não pode ser alcançada mediante a imposição de sanções a indivíduos ou grupos, efetiva ou supostamente responsáveis por eventuais transgressões morais. A moralidade estigmatizadora e penalizante é cínica num contexto de uma sociedade que nunca se dispôs a rever profunda e radicalmente suas tradiçōes e costumes, seus preconceitos e elitismos, suas discriminações de raça, de gênero, de classe; é cínica, também, no contexto de um modelo político-econômico-jurídico que se orienta no princípio, por natureza excludente e injusto, do utilitarismo que sistematicamente prioriza os interesses individuais.

Há, sem dúvida, razões em profusão para culpar os políticos por seu mau exemplo no manejo da coisa pública; para responsabilizar os pais e as famílias por não darem aos filhos uma orientação moral firme e segura; para acusar a escola e os educadores por priorizarem apenas o lado técnico/instrumental da educação e menosprezar a dimensão moral de sua prática educativa; para diabolizar a mídia por estimular a individualidade e a competitividade. De fato, são muitos os que levantam suas vozes exigindo uma renovação moral da sociedade. No entanto, seus gritos são calados no ambiente opaco de uma cultura que se tornou tolerante com as imoralidades que favorecem aos interesses ora de uns, ora de outros. O espaço da moralidade pública foi invadido pelos interesses privados, criando uma promíscua e permissiva relação entre o público e o privado no foro jurídico, político, econômico familiar e educacional, capaz de abafar, após breves espasmos de revolta, as mais acintosas afrontas à moralidade pública. Só assim se explica, por exemplo, que os sucessivos escândalos públicos dos últimos dez ou vinte anos continuem absolutamente impunes no Brasil. 
Se for correta essa análise, pode-se inferir que mudanças verdadeiras só podem ser alcançadas mediante um processo de profunda crítica cultural que envolva os arquétipos culturais que veladamente 'naturalizam' e toleram a imoralidade, na medida em que essa atende a certos interesses. Penso num debate honesto, profundo e democrático das dimensōes histórico-culturais de nossa tradição moral na economia, na política, na família, na escola e na mídia. A moralidade não é apenas responsabilidade ou culpa desse ou daquele indivíduo, desse ou daquele grupo, dessa ou daquela instituição, mas da sociedade como um todo. A moralidade social exige o aporte crítico da filosofia, da antropologia, da história, da ciência política, do direito, da teoria educacional, das ciências da comunicação, da sociologia, da psicologia, da economia, da epistemologia e da teologia, tanto para desvendar suas armadilhas cínicas, quanto para construir um espaço público no interior do qual se realize um amplo debate ético sobre os princípios a partir dos quais se julgam as decisões e as açôes.

Dizer que a responsabilidade é de todos não significa dizer que ela não é de ninguém. Ao contrário, significa que cada segmento social, cada instituição, cada indivíduo deve assumir responsabilidade moral em seu âmbito de atuação. Por sua inegável influência sobre a formação das futuras geraçôes, cabe aos setores diretamente envolvidos com a educação, como a família, a mídia e a escola, um papel particularmente relevante na reforma moral da sociedade. $\mathrm{Na}$ reflexão que farei a seguir, volto a atenção para o sentido da formação moral na educação formal, tentando argumentar, de um lado, contra a tese de que a escola é a responsável pela formação moral de seus alunos, no sentido de um enquadramento ou disciplinarização moral e, de outro, contra a idéia de que a educação formal deve limitar-se à tarefa técnica de transmissora de conhecimento. Ao contrário desses dois mandamentos, freqüentemente defendidos, desejo argumentar a favor de uma educação moral do sujeito que implique, ao mesmo tempo, a tematização crítica do ethos que, com seus conceitos, tradiçôes e costumes, representa o espaço que legitima a atuação moral desse sujeito/cidadão.

A título de roteiro, vou dividir minhas consideraçōes em cinco breves tópicos, deixando claro, desde o início, que muitas das questôes se imbricam e deveriam, na verdade, ser discutidas concomitantemente. Primeiro, vou tentar elucidar um pouco a distância entre o discurso moral e a prática na atualidade. Em segundo lugar, tento justificar que 
faz parte das tarefas da educação formal promover a educação moral dos alunos. A seguir, volto a atenção para os dois principais interlocutres da educação moral na escola: crianças e professores. Num quarto momento, faço algumas sucintas referências aos objetivos da educação moral realizada na escola. Segue-se a pergunta a respeito das condições necessárias para a realização dessa educação moral. Concluo com algumas considerações em torno de dificuldades, conflitos e ambivalências com as quais se defronta a educação moral no contexto da sociedade contemporânea.

\section{Porque se fala tanto em moral hoje?}

$\mathrm{Na}$ verdade, a resposta a esta questão é muito simples: fala-se tanto de moral porque os problemas morais assumem dimensões assustadoras na sociedade contemporânea. Isso não significa que em outros tempos esse tema não tenha sido relevante. Os textos dos mais destacados e infuentes pensadores, filósofos, historiadores, políticos e literatos de todas as épocas nos fornecem um vasto material que comprova a constante preocupação com a ética e a moral. Porém, ao contrário do passado, o tempo atual vive grandes e céleres transformações que afetam não só o exterior, mas também os fundamentos do ser e do pensar, as formas de julgar e decidir, as normas e os valores. As referências que permitem distinguir o bem do mal, o justo do injusto assumem ares de volatilidade, de relatividade, de opacidade. Além disso, o desenvolvimento científico-tecnológico nos diversos campos do saber, como a física, a química, a biologia, a genética, a comunicação etc., amplia o poder de intervenção do ser humano sobre a natureza e a vida com conseqüências assustadores e imprevisíveis. Em qualquer ambiente da sociedade contemporânea, as decisões e as açóes podem ter efeitos ameaçadores não só para os indivíduos, mas para a sociedade como um todo. E, por último, vivemos um tempo histórico em que se registra um esgarçamento das fronteiras entre o público e o privado, permitindo que o espaço público seja refuncionalizado em proveito do privado.

Os amplos traços desse cenário assumem contornos mais nítidos se focarmos o olhar sobre alguns aspectos mais tópicos. Assim, apesar de todas as promessas e expectativas de progresso e de solução dos problemas humanos, formuladas no início da modernidade (Kant, 1969), uma grande parte da população mundial continua faminta, analfabeta, doente e moribunda. Isso ocorre num momento em que já existem 
Educação moral hoje: cenários, perspectivas e perplexidades

os recursos técnicos e econômicos suficientes para reverter esse quadro. Após o "desencantamento" do mundo medieval (Weber, 2005, p. 49), ordenado pelo modo divino, a modernidade assume a instituição da ordem como criação humana. "A existência é moderna", diz Bauman, "na media em que é produzida e sustentada pelo projeto, manipulação, administração, planejamento" (1999, p. 14). Foi no interior desse projeto que germinou a profunda ambivalência entre o avanço científico-tecnológico que ensejou a abundância de bens culturais e materiais e a miséria, o atraso, a carência de milhões de pessoas. Dessa condição fundante de exclusão que, para muitos, é inerente ao sistema político/ econômico vigente, decorre a pergunta a respeito da natureza moral desse sistema.

A contradição entre a abundância e a miséria gera um ambiente de barbárie que violenta as relações em todos os espaços da vida: na família, na escola, nas ruas, nas empresas, nas relaçôes internacionais. Em todos esses âmbitos observa-se uma incrível banalização da vida porque a vida é demais. A partir da modernidade, a plenitude da vida já não deveria ser buscada na transcendência, mas na imanência. Ora, se o sentido da vida se esgota na felicidade terrena e se esta não puder ser alcançada senão por alguns, a vida (pelo menos para muitos) perde o sentido e não merece ser respeitada como valor.

A falta de trabalho exclui multidões da atividade laboral, que é precisamente o processo constituinte do ser humano (Pochmann, 2004). $\mathrm{O}$ desemprego fere o homem em sua essência, pois agride a humanidade do ser humano, impedindo-o de participar condignamente da construção de sua própria identidade. Ironicamente, o autor do desenvolvimento e do progresso é excluído e condenado a uma violenta e agressiva competitividade que não só legitima a agressão e a eliminação do outro, mas se transforma numa das mais excelsas virtudes do nosso tempo.

A agressão ao meio ambiente gera uma vulnerabilidade de proporçôes inusitadas que ameaça a sobrevivência da própria humanidade. A poluição da água, do ar e da terra, bem como a poluição visual, a sonora e a olfativa, são, todas elas, conseqüência da intervenção irresponsável sobre o meio ambiente, que pode ter efeitos terminais, conforme alertam os cientistas de todo o mundo. O mesmo se aplica à manipulação genética, ao uso de hormônios, ao emprego de insumos químicos, visando o lucro rápido sem considerar as conseqüências de longo prazo. 
As doenças, epidemias, vírus, gripes se disseminam vertiginosamente pelos caminhos rápidos (até mesmo eletrônicos) que ligam povos e culturas. Os que dispóem de recursos constroem barreiras, criam anti-vírus, conseguem proteger-se, enquanto os demais definham, morrem. Parece claro que os frutos do trabalho social, materializados no conhecimento, favorecem mais a uns e menos a outros.

A vergonhosa onda de corrupção que se abate, cínica, perversa e espetacularizada, sobre o espaço público, gera uma reação de repúdio talvez sem precedentes no país. Para além dos casos específicos de imoralidade pública, aparece no horizonte a ameaça da falência das instituições sociais ante o fenômeno de miscegenização entre o público e o privado, que ameaça os próprios fundamentos do estado de direito.

Resumindo estes itens, aos quais poderiam ser acrescentados tantos outros, pode-se dizer que estamos vivendo um domínio sem precedentes da razão instrumental e utilitarista (Adorno, 1985), para a qual os fins justificam os meios. Conceitos como eficiência, eficácia, lucro, domínio e vantagem assumem posição central nas relações humanas da sociedade contemporânea. O princípio da performatividade, do bom funcionamento, torna-se o critério de avaliação das ações individuais e coletivas. Com isso, a sociedade capitalista neoliberal assume diretrizes morais que invertem o imperativo da ética kantiana, não apenas permitindo, mas condicionando o bom funcionamento do sistema ao uso do homem como meio.

São esses cenários preocupantes e desoladores que provocam esta verdadeira explosão do debate moral que ecoa o tempo todo nas famílias, nos espaços políticos, na Igreja, na universidade e na escola. A grande pergunta que se coloca ao homem e à sociedade contemporânea, do ponto de vista moral, é como encontrar uma resposta à pergunta: $\mathrm{O}$ que significa 'tu deves'? Em outros termos, como podemos encontrar novos fundamentos para o dever.

Se, na condição de educadores morais, dissermos ao aluno 'tu deves' e ele perguntar 'porque devo', qual a resposta que lhe daremos? Os gregos argumentaram que 'devemos' por causa do Bem e da destinação natural do homem para o Bem. Os cristãos medievais acreditaram que 'devemos' por mandato de Deus. Os modernos argumentam que o dever se baseia na razão. Desde então, as respostas são muitas e variadas. De modo geral, associa-se o dever à condição de sobrevivência 
ou à conquista da felicidade. Mais recentemente, os pós-modernos (Lyotard, 1985; Lipovetsky, 1989; Bauman, 1997; Vattimo, 1996) anunciam o fim do dever nos moldes tradicionais e proclamam que as formas de comportamento devem ser decididas no contexto, nas circunstâncias.

Esta resposta se relaciona à natureza da sociedade contemporânea que se encontra em rápidas transformações; uma sociedade em que tudo o que é estabelecido logo se desfaz; uma sociedade em que tudo se centra nos interesses do indivíduo; uma sociedade em que o privado se sobrepõe ao público; uma sociedade em que as possibilidades de influência e manipulação da natureza, do ser humano e da vida assumem dimensões assustadoras.

São essas perplexidades que estão na raiz da grande visibilidade que alcança o discurso moral hoje. As pessoas sentem-se órfãs de parâmetros de comportamento. Os mais jovens, vivendo o espírito da época, são contrários a qualquer tipo de autoridade. Os adultos sentem-se inseguros, des-autorizados, sem saber o que dizer aos jovens. Serão corriqueiros o assombro e a desorientação das pessoas diante do futuro da sociedade se prosseguirem as práticas que afrontam qualquer sentido de bem comum, de justiça social. Por vezes, as pessoas parecem cansadas de lutar por uma sociedade melhor diante das dimensões assustadoras da barbárie; preferem desistir, encerrar-se na sua privacidade, abandonar o político, desestimuladas pela sensação de impotência perante as intermináveis séries de abusos que se sucedem diante de seus olhos. Embora seja compreensível, essa atitude encerra o grande risco de deixar o campo livre para que as contravenções sejam toleradas como uma rotina inevitável, contra a qual não há o que fazer. Penso que a luta em defesa de uma sociedade livre e justa não pode ser abandonada e acredito que à educação cabe um papel importante nessa tarefa.

\section{Compete à escola fazer educação moral?}

Vou abusar da paciência do leitor iniciando com uma citação bastante longa de Adorno, extraída do texto A educação contra a barbárie. Ali, Adorno (1995, p. 155) afirma que

(...) desbarbarizar tornou-se a questão mais urgente da educação hoje em dia. O problema que se impóe nesta medida é saber se por meio da educação pode-se transformar algo de decisivo em relação à barbárie. Entendo por barbárie algo muito simples, ou seja, que, estando na civilização do mais 
alto desenvolvimento tecnológico, as pessoas se encontrem atrasadas de um modo peculiarmente disforme em relação à sua própria civilização, e não apenas por não terem em sua arrasadora maioria experimentado a formação nos termos correspondentes ao conceito de civilização - mas também por se encontrarem tomadas por uma agressividade primitiva, um ódio primitivo ou, na terminologia culta, um impulso de destruição, que contribui para aumentar ainda mais o perigo de que toda a civilização venha a explodir, aliás, uma tendência imanente que a caracteriza. Considero tão urgente impedir isto que eu reordenaria todos os outros objetivos da educação por esta prioridade.

Esta citação de Adorno traz dois elementos importantes para o nosso contexto. Primeiro, o autor afirma que é de fundamental importância evitar a barbárie, o que significa dizer que a formação moral deve ocupar o lugar central na educação e, segundo, que é preciso saber se, efetivamente, a educação pode fazer algo nesse sentido. Esta última questão Adorno responde com simplicidade, dizendo que, se conseguirmos colocar o tema da barbárie no centro da consciência pedagógica, a educação já estará fazendo muito. Nesse posicionamento está subentendido que, se a educação não tematizar a barbárie, ela poderá favorecê-la indiretamente. Numa palavra, é fundamental que, para evitar este risco, a educação seja transparente em sua finalidade humana, o que significa assumir uma postura moral.

Se, de um lado, o postulado do dever ameaça caducar, de outro, reatualiza-se com notável vigor a preocupação moral em todos os segmentos da sociedade. E a pergunta a respeito do que a educação pode fazer para ajudar a reduzir a barbárie está na boca de todos e se coloca como responsabilidade para aqueles que pensam e fazem educação. Mesmo reconhecendo não ser o remédio para todos os males, a educação pode oferecer uma contribuição importante e, quem sabe, indispensável para corrigir as injustiças do mundo e contribuir para a construção de um mundo social menos desumano e mais responsável. Se, para evitar uma colaboração inconsciente e indesejada com a barbárie, a educação deve ser "transparente em sua finalidade humana", como diz Adorno, é necessário que a escola tenha consciência disso e saiba traduzir em sua prática tal sentido humano. E, para adiantar o que será retomado mais adiante, entendo que a educação tem um papel fundamental na formação do sujeito moral, crítico e autônomo, dando novos e transformadores rumos ao movimento dialético entre o indivíduo e a coletividade. 
Mesmo admitindo que nos encontramos nos momentos finais da era do dever, no sentido tradicional e moderno, isso não significa que devamos assistir ao declínio de todas as virtudes. ${ }^{1}$ A boa convivência humana não dispensa normas e leis que devem ser obedecidas. Trata-se, portanto, não do fim do dever, mas de um processo de reorganização moral que leve em conta uma realidade social ordenada segundo novos princípios e formas de relacionamento. Já não temos a mão temível do divino, nem mesmo o absolutismo da razão para nos orientar em nossas decisōes e ações. É, portanto, necessário buscar outras formas de comportamento moral que sejam condizentes com as condiçóes da sociedade e do homem contemporâneos. Esta é a tarefa na qual está envolvido um vasto colégio de pensadores que congrega representantes das mais diferentes áreas de conhecimento.

Reconhecer as circunstâncias e os homens tal como são não significa que esta realidade deva ser transformada em paradigma de moralidade. Não se pode confundir o ser, a realidade como ela é, com o dever ser, a realidade como ela deveria ser. Hoje, usufrui-se o presente, o eu, o conforto, o corpo, o prazer. Esta é a nova retórica do carpe diem que veio substituir a antiga retórica do dever. É isso que os alunos trazem para a escola e é isso que, como veremos adiante, a escola deve tomar como ponto de partida para qualquer proposta de educação moral. É neste contexto que precisa ser inventado um novo discurso ético. O sentido da responsabilidade moral precisa reconstituir-se em novas bases em meio à tendência individualista e hedonista que caracteriza o presente.

As crianças e os jovens passam grande parte de sua vida na escola. Nesse tempo forma-se sua sensibilidade, sua maneira de pensar e de julgar, se moldam seus conceitos e representações, se enraízam atitudes e comportamentos. Todo esse desenvolvimento que acontece ao longo dos anos escolares representa a constituição da identidade do sujeito com suas diferentes, mas complementares faces do epistêmico, do estético e do ético. Mesmo que defendêssemos o ponto de vista de que a educação não deveria ocupar-se da formação moral dos seus alunos, seria impossível negar que, de uma forma ou de outra, no contexto escolar das relações professor/aluno, dos livros didáticos, das avaliações, estariam sendo transmitidos ideais e imagens de homem, de mundo, de relacionamento, de normas e valores. A influência moral sobre os alunos é impossível de ser evitada no ambiente escolar. Assim sendo, 
parece razoável que isso não aconteça de forma inconsciente e difusa pelo assim chamado currículo oculto, mas que seja explicitada, discutida e orientada para a formação de um sujeito moral autônomo, crítico e responsável. Retomando o pensamento de Adorno, é necessário que a educação seja transparente em sua finalidade humana, assumindo uma postura moral. Veremos mais adiante como isso pode ser feito. Antes, é preciso registrar que o ponto de partida de qualquer projeto de educação moral é conhecer bem os dois personagens envolvidos na formação ética realizada na escola: o aluno e o professor.

\section{Quem são os alunos e quem são os professores?}

Podemos iniciar lembrando uma evidência que, por vezes, não é devidamente levada em conta. As crianças não chegam à escola como folhas em branco, completamente abertas para receberam as marcas de uma formação moral que a escola tem para oferecer. Ao contrário, a escola acolhe pessoas que já se encontram em formação, com múltiplas influências e determinações, das quais muitas certamente são definitivas, ao passo que outras ainda estão abertas à transformação. Todo ser humano, embora nasça com uma certa carga genética, começa a constituir-se, a formar sua identidade desde o nascimento pelas experiências e aprendizagens que acontecem no contexto das relaçôes familiares, sociais e midiáticas.

As normas e convenções que ordenam a vida do grupo em que a pessoa cresce ou que são mediadas pelos meios eletrônicos, os gestos, as atitudes, os conselhos, os movimentos, os humores etc., vão sendo absorvidas e incorporadas pelo indivíduo no ambiente simbiótico de suas relações com o meio. Os gregos falavam de uma téchne tou biou, ou seja, de uma técnica ou de uma arte de vida que relaciona o indivíduo ao ethos, à maneira de ser da comunidade. Por isso, a criança quando chega à escola já é portadora de uma vasta experiência, de uma história relativamente longa de formação que envolve não só conhecimentos, sensibilidades, mas também representações de valores, formas de julgamento e de comportamento. Importa lembrar que até esse momento a formação da criança é predominantemtne heterônoma, ou seja, predomina a absorção inconsciente das influências vindas de fora.

A escola, portanto, deve receber a criança como um ser já formado, embora não plenamente, pelo contexto social em que viveu e 
continua vivendo. Aliás, isso pode representar o primeiro grande desafio da formação ética: estabelecer uma relação não-traumática entre a identidade já constituída da criança e o imaginário moral vigente na escola. A escola deve receber a criança não para julgá-la, mas para despertar nela a consciência de sua própria realidade, de sua própria história e, assim, criar condiçóes para que ela, aos poucos, possa assumirse como autora de sua própria identidade, constituindo-se como sujeito moralmente autônomo e capaz de tomar nas próprias mãos o seu destino no interior da comunidade.

Como veremos adiante com mais detalhe, algo semelhante, embora se encontrem em outro estágio de suas vidas, pode-se dizer também dos professores. Eles não são sujeitos etéreos que pairam acima da realidade. Ao contrário, são pessoas envolvidas e afetadas nas suas convicções, sensações, aspirações como qualquer outra pessoa que conviva com os conflitos e ambivalências éticas e morais da sociedade contemporânea.

Diferentemente de períodos anteriores, em que os valores, as tradições e as normas eram mais estáveis, hoje tudo é volátil e mutante. Esse caráter histórico tornou-se um dos elementos centrais de toda a educação e da educação moral em particular. Em decorrência dos modos de pensar, de julgar e de agir, multiplicam-se, também, as estratégias de influências sobre os indivíduos, particularmente aquelas empenhadas na adaptação das pessoas ao sistema e seus interesses. A criança chega à escola já familiarizada com e influenciada por uma diversidade muito grande de opinióes, de posicionamentos a respeito dos mais diferentes assuntos; chega influenciada por posicionamentos religiosos, ora herméticos e dogmáticos, ora soltos e descomprometidos; chega marcada por imagens de violência, de erotismo, de relaçôes utilitaristas; chega, sobretudo, seduzida por anseios, desejos, modelos de felicidade relacionados às prioridades do mercado, do consumo, do lucro.

Nesse contexto, os meios de comunicação surgem como novo e poderoso mecanismo de infuência heterônoma na educação das pessoas, inclusive na sua formação moral. De fato, é a mídia, com seus interesses ligados ao modelo social capitalista, que fixa muitas das causas prioritárias que estimulam a orientação e o comportamento dos indivíduos, que emocionam os coraçóes hedonistas e desculpabilizam as consciências pelo abandono de suas responsabilidades morais e sociais. $\mathrm{Na}$ verdade, a mídia, hoje invasiva ao extremo, serve-se dos mais refinados 
recursos técnológicos, lingüísticos e imagéticos para influenciar e seduzir. Ao contrário do que muitas vezes se pensa, essa influência não se limita à venda de produtos, mas usa seu poder de sedução para conformar seu modo de pensar, de sentir, de agir e de ser, "impedindo a formação de indivíduos autônomos, independentes, capazes de julgar e decidir conscientemente" (Adorno, 1986, p. 99).

O certo é que as crianças chegam à escola com uma identidade que já sofreu múltiplas influências, positivas e negativas, da família, do meio, da televisão, da internet. Essa é uma realidade que qualquer projeto de educação moral deve considerar como ponto de partida. $\mathrm{O}$ mais grave e perverso dessas influências é que elas não apenas se agregam quais adereços à identidade individual em constituição, mas representam, na verdade, elementos estruturantes da própria personalidade. Dessa forma, tornam-se resistentes, não encontrando outra forma de superação senão pela conscientização psicanalítica e crítica das determinaçôes sócio-culturais da personalidade. Se pelas influências do sistema e de suas instituições o homem se torna egoísta através da multiplicação e exaltação dos interesses privados, como transformar esse indivíduo privado, cujo ideal de felicidade é a satisfação de seus interesses egoísticos, num cidadão preocupado com o bem comum? É esta a realidade que justifica a tese inicialmente levantada de que o educação moral não pode ser vista apenas como a educação dos indivíduos, a partir de certos princípios ou normas morais. Esta será sempre uma tarefa sisífica de eterno e frustrante recomeçar, enquanto o sistema continuar gerando filhos contaminados de imoralidade. É, portanto, necessária a perpectiva mais ampla da renovação moral da sociedade como um todo.

$\mathrm{Na}$ outra ponta da relação formativa, encontra-se o professor que, a exemplo das crianças ou dos jovens, também está exposto às permanentes influências do meio. Não se pode imaginar que para se realizar um projeto de educação moral seja suficiente a manifestação de bons propósitos e a conclamação de professores para que eles assumam seu papel de formadores. É preciso, antes disso, que os docentes tenham uma correspondente formação, que tenham passado por um processo de conscientização de sua própria moralidade, de seus ideais e sentidos de homem, de mundo e de vida, dos fundamentos que orientam seu julgar e agir, para só então, e a partir daí, pensarem no papel que lhes cabe como agentes da formação moral. Mais ainda: como agente de 
formação moral, o professor não fala sozinho, mas com ele fala todo o contexto escolar, ou seja, na educação moral escolar está sempre envolvida a escola como um todo. Na verdade, é este todo, com suas diferentes vozes, desde o diretor ao funcionário, desde os conteúdos aos procedimentos didáticos, desde os momentos formais aos lúdicos, que representa o verdadeiro agente da educação moral.

Formar professores com sensibilidade moral significa familiarizálos criticamente com as imagens de mundo, de ser humano, de meio ambiente, com conceitos como liberdade, responsabilidade, respeito, tolerância; significa despertar neles a sensibilidade para as formas mais dignas, justas, belas e felizes de se viver, de modo que eles, por sua vez, possam despertar em seus alunos sensibilidades semelhantes. Esta perspectiva ético-estética abandona o sentido regulador, enquadrador e identificador da ética tradicional para despertar nos jovens a percepção e a responsabilidade diante da desestetização que representa a miséria, a injustiça, a fome, enfim, a barbárie. Para avançarmos um pouco no esclarecimento dessa importante questão, parece adequado perguntar quais são os objetivos da formação moral.

\section{Quais os objetivos da educação moral?}

Como já foi dito anteriormente, o modelo de um ordenamento moral de princípios e de regras estáveis pertence ao passado. Hoje, tudo está em permanente tansformação: o que valeu ontem pode não valer hoje e o que vale hoje pode não servir amanhã; o que é tido como certo num determinado contexto cultural pode não ser correto em outro. Impóe-se o entendimento de que os princípios e as regras universais perdem sua força a favor de novas convenções, que dependem dos contextos culturais. Pode-se dizer que se ampliam e flexibilizam os limites dos sentidos e, com isso, os limites do sujeito e do mundo. Como na arte, a vida parece ser uma permanente renovação de regras e de preceitos.

O contexto contemporâneo de paulatina desconstrução dos valores e normas tradicionais exige outras formas de legitimação. Pressupondo, como parece plausível, que os homens não conseguem conviver pacificamente sem normas que regulamentem suas condutas e sabendo, também, que tais normas não podem ser deduzidas de princípios transcendentais, é necessário dar-lhes legitimidade com base em outro 
procedimento. Já no início da época moderna, Rousseau (2007), Hobbes (2006) e Hume (1995) propuseram a idéia do contrato social. Mais recentemente, Habermas (1989) e Rawls (1993) sugerem a idéia de consenso a ser encontrado mediante o diálogo. Este novo procedimento de legitimação tem conseqüências consideráveis tanto para o sujeito que simplesmente cumpre normas, quanto para aquele que exige o cumprimento de normas. Para o primeiro não é suficiente obedecer cegamente às normas, porque, desde a modernidade, o sujeito moral assume a corresponsabilidade pela legitimidade das normas. Se, na moral tradicional, Abrahão podia matar seu filho sem incorrer em crime porque obedecia a Deus, a partir da modernidade, mesmo obedecendo a Deus, Abrahão seria criminoso, porque o argumento da autoridade não mais o isentaria da responsabilidade pelo homicídio. De outra parte, para o educador não é suficiente exigir obediência em nome de alguma autoridade: ele precisa tornar plausível a legitimidade das normas. No primeiro caso, é necessário responder à pergunta em nome de quem se obedece e, no segundo, em nome de quem se exerce a autoridade moral. Exigese, portanto, um elevado nível de consciência e de responsabilidade. Hoje, é necessário dar voz à vida do indivíduo e da comunidade em meio ao calor e à fragilidade da realidade. A linguagem evocativa é substituída por uma linguagem palpitante, que tenta dizer o que nunca foi dito, que busca abrir trilhas em meio a cenários nunca antes visitados. A todo instante mudam os cenários na biologia, na medicina, na genética, na comunicação, na política, na economia, gerando sempre novos desafios para a reflexão ética e, consequentemente, para as decisões e ações morais.

Esse deslocamento dos fundamentos da moralidade do céu para a terra, da transcendência para a imanência, tem enormes implicações para qualquer projeto de formação moral. No bojo dessa reviravolta, ocorre a passagem da visão providencialista e fatalista da história para uma visão puramente humana e histórica. Com isso, dissolve-se a fonte que legitimava a educação moral tradicional e perde força o argumento da autoridade em nome do qual se exigia submissão e obediência. Encontramonos em meio a essa passagem, com os olhos ora voltados para o passado, ora para o futuro, entre a saudade e a esperança, vivendo intensamente as ambivalências de um mundo em transformação.

Ao tempo em que as mudanças ocorriam de forma mais lenta, o homem tinha condições de olhar para o passado e ver nele espelhados o presente e as expectativas de futuro, de modo que tinha como orientar-se, 
Educação moral hoje: cenários, perspectivas e perplexidades

sentir-se seguro, em relação ao curso dos acontecimentos. Nesse contexto de estabilidade, justificava-se uma educação moral baseada no argumento da autoridade, que exigia sujeição e obediência ao conjunto de normas e valores aceitos por todos. A educação moral consistia na repressão dos desejos e instintos e na incoporação do ethos legitimado pela tradição. Hoje, as tradições se encontram sob suspeita, perderam sua força orientadora e não oferecem mais amparo e segurança diante de um futuro inseguro e imprevisível.

Essa condição cultural tem decisivas conseqüências para a formação moral das pessoas. De um lado, como vimos, a educação moral nos moldes tradicionais da adaptação a um código ético de traços universais e permanentes já não é possivel. De outro, pela dissolução das referências, o homem corre o iminente risco de submergir na mudança, de ser envolvido, absorvido e levado pelo fluxo da existência, sem conseguir assenhorear-se do seu próprio caminho e destino. Para que isso não ocorra e para que não impere a lei do mais forte, são necessários códigos de conduta, normas e valores que devem ser respeitados por todos. É o preço da condição humana: a liberdade de todos exige o limite da liberdade individual. Apesar das teses que falam do fim dos valores (Lipovetsky, 1989), dos tempos líquidos (Bauman, 1999), as permanências, as referências, as normas e valores são condições necessárias da vida humana. Não há sociedade humana nem convivência ordenada e pacífica sem um código de direitos e deveres, orientador da coexistência dos indivíduos. O que ocorre é que este código não é mais indelével, permanente e universal, mas histórico, ou seja, sujeito a transformações e mudanças que acompanham as condições materiais e culturais da sociedade. Essa ambivalência entre a permanência e o fluxo, entre a tradição e o porvir, entre o ser e o vir-a-ser é o centro da paideia contemporânea. ${ }^{2}$

Nesse cenário, a tarefa da educação moral coloca-se numa nova perspectiva de formar um sujeito moral, portador de uma consciência crítica que lhe permita uma permanente percepção e avaliação da pertinência dos códigos, normas, tradiçôes, na perspectiva da liberdade e da justiça. A liberdade é condição seminal de qualquer moralidade, uma vez que sem liberdade não há decisão nem ação moral, e justiça é condição antropológica do ser humano como ser social, que precisa encontrar formas de convivência em que direitos e deveres se equilibrem. Por isso, formar sujeitos morais não significa, pelo menos não significa 
apenas, transmitir esse ou aquele valor, exigir esse ou aquele comportamento, mas contribuir para tornar o indivíduo um sujeito crítico, político, reflexivo. Compete ao professor despertar nos seus alunos o desejo de ser um sujeito moral. Esse é fundamentalmente um processo dialógico, argumentativo, de convencimento. Ninguém pode obrigar alguém a ser um sujeito moral contra a sua vontade, nem mesmo mediante as mais severas ameaças ou sanções, pela simples razão de que a liberdade é condição sine qua non da moralidade. Obedecer às normas, seja por conforto ou temor, é condição suficiente para ser correto (em conformidade com as normas), mas não para ser um sujeito moral. A ação moral tem como pressuposto a livre escolha do sujeito. E essa condição de sujeito moral autônomo não existe a priori, nem pode ser simplesmente transmitida pela educação: é uma condição que deve ser conquistada e continuamente fortalecida ao longo de toda a vida. Ajudar nesse intuito é o sentido e o objetivo da formação moral.

Erigir liberdade e justiça em princípios centrais de um novo modelo de moralidade implica repensar profundamente a relação entre individuo e sociedade, estabelecendo novos vínculos que agregam as tônicas fundantes dos modelos ético-filosóficos da antiguidade e da modernidade, focados, como se sabe, respectivamente, na justiça e na individualidade. Sociedade e indivíduo são as duas faces imbricadas de uma mesma realidade social.

O ser humano, por ser dotado de razão, é um ser confiado a si mesmo, que deve cuidar de si, velar por si mesmo. Dessa premissa ele não pode abrir mão, sob pena de deixar de ser humano. $\mathrm{O}$ sujeito moral só se constitui a partir do trabalho que faz consigo mesmo como exercício de conquista de sua liberdade. $\mathrm{O}$ estado que o indivíduo deseja é o estado de soberania e independência de si mesmo, numa palavra, de autonomia com relação a si mesmo, às coisas e ao mundo. Desse objetivo maior decorre a pergunta a respeito da conduta ou das regras que devem ser assumidas para alcançar esse estágio de autonomia.

Combater a imoralidade significa, então, o homem repensar-se como sujeito moral; repensar-se como indivíduo, em sua história pessoal, nas suas relações com os outros seres humanos e com a natureza; significa repensar a sua situação no mundo contemporâneo, o sentido de sua vida presente e futura, as suas formas de convivência e usos dos outros e da natureza. Mas significa, também, repensar a sociedade, seus objetivos e ideais, seus valores e normas, seu sistema jurídico, político 
e econômico, na perspectiva da convivência digna e justa. E é no contexto dessa relação entre o individual e o social, como dimensões fundantes da moralidade, que o conceito de justiça adquire nova e inarredável centralidade. A justiça é a primeira e mais fundamental virtude do homem contemporâneo. $\mathrm{O}$ eixo dessa nova perspectiva consiste na relação indissolúvel entre o indivíduo e a sociedade. Restabelecer esse vínculo entre indivíduo e sociedade, em meio a um contexto cultural em que tal vinculação se apresenta estremecida, parece-me o objetivo central de educação moral. Não existe o sujeito moral independente da sociedade e nem a sociedade moral independente do sujeito moral: ambos mantêm entre si vículos indissolúveis de liberdade e de justiça. Liberdade é o escopo e justiça sua condição. Nesses termos, não há liberdade sem justiça e nem justiça sem liberdade.

Se fosse resumir essas considerações, diria que a educação moral se baseia, em termos de procedimento, no diálogo e na argumentação, e, em termos de objetivos, na formação do sujeito moral crítico, autônomo e livre, cujas principais virtudes devem ser a responsabilidade e a justiça. No entanto, a realização desse objetivo enfrenta, na prática, grandes dificuldades, uma vez que as tendências hegemônicas nos contextos sócio-cultural-econômico se orientam em sentido contrário. A seguir, serão apontadas algumas dessas dificuldades.

\section{Dificuldades, conflitos e ambivalências}

Podemos distinguir várias situações que configuram posicionamentos distintos com relação à educação moral. O primeiro é representado por aqueles que, diante do mundo barbarizado em que vivemos (Mattéi, 2002), sentem-se desiludidos e impotentes e não acreditam que algo possa ser mudado pela educação moral. No interior da escola, existem também os que, atropelados pelo cotidiano de tantas tarefas, burocracias e frustrações, tornam-se indiferentes, optando por cumprir suas obrigações sem altruismos nem projetos. Há também o grupo dos saudosistas que constantemente comparam os "bons tempos" com as desgraças morais contemporâneas e sonham com o retorno ao passado das normas claras, da ordem e do dever. Finalmente, existem os que fazem coro a um certo discurso de senso-comum, lamuriento, acusativo e catastrofista, que se sentem vítimas e não se cansam de culpar os outros. 
Em meio à tensão entre essas várias situações, a escola é acometida por uma profunda crise. Ao mesmo tempo em que a escola é responsabilizada pela formação moral dos alunos para compensar o vazio formativo aberto pelo esfacelamento da família, pela influência desencontrada da mídia e pela desorientação ética geral da sociedade, ela é solicitada a dedicar-se a adaptar os alunos à sociedade, transmitir-lhes conhecimentos e habilidades, de modo que possam ter uma vida de sucesso. Esta crise é essencialmente a crise da Bildung, da formação do homem integral, individual e social, que se esfacela sob a desmesurada submissão da educação às exigências de um modelo de vida que se divide entre os prazeres imediatos, as vantagens materiais e as exigências do mercado. Sob a alegação da necessidade de atender às incontornáveis exigências desse modelo de existência, ou seja, de realizar uma educação utilitarista que adapta os indivíduos à realidade, a escola é fortemente constrangida a abrir mão de uma de suas mais importantes responsabilidades, que é a formação integral do ser humano em sua dimensão epistemológica, estética e moral. Essa, então, é a primeira grande dificuldade: exige-se, de um lado, uma educação voltada para o mercado, para a competividade, para o útil e, de outro, uma educação do sujeito moral responsável, respeitoso, justo. São duas propostas não apenas distintas, mas em boa medida contraditórias, uma vez que, como veremos adiante, o atendimento aos mandados do mercado fere, em muitos aspectos, os princípios da moralidade. Essa situação gera um clima de indiferença e impotência entre os docentes que, descrentes das reais possibilidades de uma educação moral, parecem cada vez mais reféns de um sistema que deles exige "virtudes" opostas aos parâmetros de uma moralidade fundada no respeito, na dignidade, na tolerância, na justiça e na democracia.

Essa situação de um certo marasmo moral confere incrível atualidade à pergunta formulada por Hobbes: "Por que os homens devem atuar de outra forma que não seja em função de seu próprio proveito imediato?". Esse é o ponto nevrálgico e a dificuldade maior da educação moral hoje. Enquanto tudo se foca no indivíduo, nos seus interesses, nos seus desejos, vantagens e prazeres, a educação moral precisa, remando a contracorrente, cultivar o respeito, a responsabilidade e a justiça. Nesse sentido, a educação moral torna-se uma tarefa complexa que envolve o grande desafio da contrafaticidade, uma vez que a tendência educacional dominante é a da acomodação, da adaptação, do 
Educação moral hoje: cenários, perspectivas e perplexidades

enquadramento das pessoas a uma realidade orientada pelos interesses do sucesso pessoal, da posse de bens e do exercício do poder.

Tal tarefa torna-se ainda mais difícil se levarmos em conta que o cuidado do indivíduo consigo mesmo passou a representar, desde a modernidade, não mais a negativa renúncia do eu, comum na moral cristã, mas uma conquista positiva de constituição do eu. Temos então a ambivalente exigência de, ao mesmo tempo, promover o desenvolvimento do indivíduo, com sua liberdade e autonomia, e despertar nele o espírito de socialidade respeitosa, tolerante e responsável. Encontrar um equilíbrio entre os interesses individuais e as necessidades sociais não é, de modo algum, uma tarefa simples. Aristóteles ensinou que a formação da pessoa tem sempre um caráter político, uma vez que o eu se constitui na estreita relação com a pólis, seus costumes, normas e valores (1999, p. 18). O ethos, de onde deriva ético, é a maneira de alguém se conduzir, sua forma de ser, de decidir e de agir diante de diferentes situaçóes no interior da comunidade. Essa dupla dimensionalidade, individual e social, do ser humano confere igual duplicidade à formação moral que visa à formação do sujeito autônomo e livre, mas sempre na condição de ser político e social. Decisões e ações são, ou pelo menos deveriam sempre ser, gestos, a um tempo, solitários e solidários de uma liberdade refletida que implica limites negociados. O indivíduo se desenvolve como ser autônomo e livre nos limites de sua humanidade política. O equilíbrio dessa dupla condicionalidade encontra garantias objetivas e democráticas nas normas e prescrições que organizam os desejos e os instintos, adaptando-os às exigências da convivência entre liberdades. A liberdade, portanto, tem sempre um caráter político, como já sabiam os gregos. Liberdade significa não ser escravo de si, dos seus instintos e dos seus apetites e, ao mesmo tempo, não ser escravo dos outros. Mas não ser escravo dos outros significa também que o outro não pode ser meu escravo. "A ação justa", dizia Arsitóteles (1999, p. 101), “é um meio termo entre o agir justamente e ser tratado justamente”. Em conformidade com essa premissa, os sujeitos não podem formar-se, conhecer-se, constituir-se independemente de sua relação com os outros. À liberdade do indivíduo, portanto, é inerente uma dimensão política e social. Disso podemos concluir que o comportamento moral está intrínsecamente relacionado ao conceito de democracia e de justiça social. E assim voltamos à pergunta de Hobbes: Como convencer os homens a não perseguirem apenas os seus 
interesses individuais? E é nisso que reside a grande dificuldade, numa época em que se privilegiam e se antepõem os interesses individuais aos sociais e comunitários.

Essa relação entre o individual e o social liga-se a uma outra dificuldade presente na educação de modo geral, mas particularmente difícil no contexto da educação moral. Trata-se do problema da disciplina e da autoridade. Todo o debate a respeito das relaçóes entre as gerações defronta-se com essa questão. Pode-se dizer que qualquer atividade humana que se propóe alcançar certos objetivos exige disciplina. Isso vale tanto para uma equipe desportiva, para uma orquestra, quanto para um grupo de pesquisa que queiram obter sucesso no seu trabalho. No entanto, desde a quebra do autoritarismo tradicional (Rousseau, 1992), tornou-se comum uma forte rejeição a qualquer tipo de autoridade, a ponto de chegarmos hoje a uma sociedade que endeusa a inexistência de limites. Particularmente a familía e a escola se defrontam com esse problema. Filhos e alunos articulam uma difusa reinvindicação de igualdade com relação aos pais e professores.

Em outras palavras, há hoje uma forte resistência em reconhecer o princípio da autoridade, em nome da qual se possa exigir disciplina. Teríamos aí um vasto campo de debates e discussões que não é o momento de explorar. No entanto, é importante registrar que essa crise de autoridade e de disciplina afeta também a educação moral, na medida em que se questiona a autoridade da norma moral. Retorna aqui o problema, já abordado anteriormente, da legitimação das normas e valores. Hoje, as normas e valores exigem uma legitimação racional, de modo que aqueles que são obrigados a segui-los possam compreender por que são obrigados a fazê-lo.

Acontece, no entanto, que esse processo de legitimação não pode ser retomado a cada instante. A vida quotidiana pressupóe uma certa durabilidade, um reconhecimento, em princípio, da autoridade, pelo fato de essa autoridade ter sido socialmente legitimada. Não é necessário dizer que isso não justifica o uso despótico dessa autoridade. É preciso que filhos e alunos estejam convencidos, primeiro, de que a disciplina e a autoridade são socialmente necessárias e, segundo, que a disciplina e a obediência, embora imponham limites aos impulsos e desejos imediatos, são vantajosas em termos da convivência civilizada. No entanto, essa argumentação é pouco convincente no contexto cultural em que predomina a eudaimonia, a busca do prazer, o sucesso e as vantagens 
Educação moral hoje: cenários, perspectivas e perplexidades

pessoais. Ocorre nesse ambiente um notável dissenso entre virtude e felicidade. Está posta, assim, essa última questão: Por que praticar a virtude se ela não conduz à felicidade?

Nas sociedades tradicionais havia um forte consenso a respeito do código de regras e dos fins sociais que deviam orientar a vida de cada um. Esse consenso se fundava na relação entre virtude e felicidade: o sacrifício da virtude era recompensado pelo ganho de felicidade. A relação entre virtude e felicidade, que preservava coesas tanto a pólis grega quanto a comunitas medieval, parece romper-se na sociedade contemporânea. De um lado, sobrevivem os ideais tradicionais de honestidade, respeito e eqüidade, formulados na Grécia como forma de vida feliz na pólis e, na Idade Média, como caminho para a felicidade eterna e, de outro, surgem os ideais da posse, do consumo e do poder que prometem a felicidade no sistema capitalista. A promessa de felicidade, que justicava as virtudes tradicionais, perdeu credibilidade e a felicidade contemporânea não necessita de virtude.

Nas sociedades em que se dissociam virtude e felicidade, a educação moral tende a constituir-se num repertório de admoestações acompanhado de promessas de felicidade que desfrutam de pouca credibilidade. Disso resulta o que poderíamos chamar de uma moral cínica do capitalismo contemporâneo, ou seja, uma moral que exige um comportamento virtuoso como, por exemplo, obedecer às leis, submeter-se aos preceitos da ordem pública, pagar impostos, dizer a verdade, ser honesto etc., sem que tais comportamentos tragam a felicidade pessoal e social nos termos da eudaimonia dominante. Pior que isso, a felicidade, muitas vezes, encontra-se do lado daqueles que burlam os princípios dessa moral. A ambivalência mais perversa desse moralismo cínico da sociedade capitalista é que esse divórcio entre regras e fins, entre virtude e felicidade, atinge particularmente as parcelas menos favorecidas da população, que não podem aproveitar-se dos benefícios do sistema alcançados pela burla da norma. Essa parte da população tem que obedecer às normas, tem que ser virtuosa para garantir o funcionamento de um sistema que, na verdade, apenas a aflige, reprime e exclui.

No modelo cristão, o comportamento virtuoso garantia a felicidade eterna para todos os que agiam em conformidade com a lei. $\mathrm{Na}$ intenção, pode-se dizer o mesmo do modelo secularizado da modernidade, pois a obediência de todos às normas do contrato social deveria garantir 
o bem-estar e a felicidade de todos. Com o surgimento do capitalismo, esta perspectiva foi alterada, na medida em que, enquanto permanece a exigência da virtude de todos, a felicidade fica reservada aos poucos que antepõem os interesses privados aos sociais. Na situação atual do capitalismo neoliberal, em que a felicidade consiste na busca do prazer imediato, chegamos ao ponto extremo não apenas da desconexão entre virtude e felicidade, mas da inversão dessa relação em antagonismo: a realização social, o sucesso, o bem estar são facilitados pela contravenção, pelo poder, pela exploração das pessoas e do meio. Uma vez ocorrida esta desconexão entre virtude e felicidade, o perigo reside em se manter a virtude na forma de pura coação ou repressão. Com isso, elimina-se a sedução da recompensa, que justifica o sacrifício, e a moral perde o sentido.

Parece ser esse o risco que corremos numa sociedade em que as virtudes tradicionais já não são o mecanismo para alcançar a felicidade, pelo menos não nos termos hedonistas em que é formulada hoje. Num contexto em que o virtuoso não raro é considerado otário, a educação moral está condenada a enfrentar enorme dificuldade. Esses comentários nos permitem retornar à nossa tese inicial de que a reforma moral do indivíduo depende essencialmente de uma simultânea reforma moral de sociedade como um todo. Como esta reforma não é possível sem os indivíduos, é tarefa primeira da formação moral estimular a formação de sujeitos políticos que tenham a justiça como seu bem maior.

\section{Conclusão}

Essa reflexão mostra com bastante clareza que a tarefa da educação moral não é apenas um compromisso dos pais, da escola ou de uma outra instância qualquer, mas um compromisso da sociedade como um todo e de todas as suas instituições políticas, jurídicas, midiáticas e também educacionais. Afirmar isso representa alimentar certa utopia, no seu sentido negativo, uma vez que, no momento, nada indica que a sociedade venha a iluminar-se em todos os seus ambientes de um novo consenso de moralidade. A sociedade será sempre plena de contradiçôes e é no interior delas que se estabelece a luta por práticas individuais e sociais que favoreçam o bem-estar e a felicidade de todos. É nessa perspectiva que deve ser vista a tarefa da educação moral realizada no interior da escola: uma tarefa árdua que se encontra entre paradoxais e 
contraditórias exigências. De um lado, sabe-se que ela precisa da tradição como condição educativa para o presente e para o futuro e, de outro, reconhece-se que ela necessita adaptar-se ao ritmo e à celeridade das mudanças e transformaçóes. Se no passado o próprio acontecer histórico tinha o sentido alegórico que ilustrava as grandes idéias de Homem, de Deus, da Natureza, idéias estas que orientavam o mundo e representavam o sentido da vida, agora o movimento não é símbolo de nada, ele é pura e simplesmente movimento, mudança sem significado exterior a si mesmo. Com o esvaziamento dos grandes cenários de sentidos e significados teleológicos, o homem perdeu sua condição de dominador e foi jogado para o interior do próprio movimento, transformando-se em parte igual a todas as outras do todo em movimento. Adorno disse, certa vez, que a grande máquina da ciência e da tecnologia cuspiu seu maquinista e criador. Talvez se possa dizer, desde um outro ponto de vista, que o ser humano não foi ejetado, mas está ameaçado de ser absorvido pela grande máquina, no interior da qual está sendo consumido pelas chamas ardentes de um progresso que avança sozinho sem dar atenção aos sentidos transcendentes do humano. Parece, então, que nos encontramos bastante distantes do homem autônomo e socialmente responsável, que é o objetivo maior de toda a educação ética. Trata-se, sem dúvida, de um ambiente muito adverso para uma educação moral, mas o imponente movimento por uma nova moralidade individual e social nos convence primeiro de que ela é absolutamente necessária e, segundo, de que ela é possível.

O caminho certamente não é nem curto nem fácil. Nem se deve imaginar que seja possivel formar os sujeitos para depois termos uma sociedade mais moralizada. A formação das pessoas e o repensar das estruturas profundas de nossa sociedade são duas faces de um mesmo processo. É preciso empreender um grande debate da coisa pública, do espaço público como o âmbito de discernimento moral, em que o conceito de justiça assume centralidade e se torna o conceito definidor da mais elevada virtude da ética contemporânea. E a escola, em todos os seus níveis, tem uma fundamental contribuição a dar: promover a renovação moral do indivíduo e da sociedade, no sentido de uma ordem mais justa.

Recebido e aprovado em julho de 2007. 


\section{Notas}

1. Sigo aqui as teses da Ética do discurso que, de um lado, "pró́be que, em nome de uma autoridade filosófica, se privilegiem e se fixem de uma vez por todas numa teoria moral determinados conteúdos normativos" e, de outro, afirma que "os juízos morais têm um conteúdo cognitivo; eles não se limitam a dar expressão às atitudes afetivas, preferências ou decisões contingentes de cada falante ou ator" (Habermas, 1989, p. 147-148).

2. Mesmo os autores considerados precursores ou pós-modernos, em sentido estrito, não colocam em dúvida a necessidade de valores. Veja-se o que diz Vattimo (1996, p. 5-6), ao analisar as posições de Nietzsche e de Heidegger: "Como essa definição coincide com o 'Deus está morto' e com a desvalorização dos valores supremos de Nietzsche? Pode-se percebê-lo ao se atentar para o fato de que também para Nietzsche não desapareceram os valores tout court, mas os valores supremos, resumidos precisamente no valor supremo por excelência: Deus. Tudo isso, porém, longe de tirar sentido da noção de valor, como Heidegger bem viu, liberta-a na sua potencialidade vertiginosa: somente onde não há instância terminal e 'interruptiva', bloqueadora, do valor supremo-Deus, os valores podem manifestar-se em sua verdadeira natureza, que é a convertibilidade, e a sua transformabilidade/processualidade indefinida".

\section{Referências bibliográficas}

ADORNO, T. Dialética do esclarecimento. Rio de Janeiro: Zahar, 1985.

ADORNO, T. A indústria cultural. In: GoHn, G. (Org.). Theodor Adorno. São Paulo: Ática, 1986. p. 92-99.

ADORNO, T. Educação e emancipação. Rio de Janeiro: Paz \& Terra, 1995.

ARISTÓTELES. Ética a Nicomacos. Brasília, DF: UNB, 1999.

BAUMAN, Z. Ética pós-moderna. São Paulo: Paulus, 1997.

BAUMAN, Z. Modernidade e ambivalência. Rio de Janeiro: Zahar, 1999.

HABERMAS, J. Consciência moral e agir comunicativo. Rio de Janeiro: Tempo Brasileiro, 1989.

HOBBES, T. Leviatã. São Paulo: Martin Claret, 2006.

HUME, D. Uma investigação sobre os principios da moral. Campinas: UNICAMP, 1995.

Educ. Soc., Campinas, vol. 28, n. 100 - Especial, p. 737-762, out. 2007

Disponível em <http://www.cedes.unicamp.br> 
Educação moral hoje: cenários, perspectivas e perplexidades

KANT, I. Beantwortung der Frage: was ist Aufklärung. In: KanT, I. Ausgewählte kleine Schriften. Hamburg: Felix Meiner, 1969.

LIPOVETSKY, G. A era do vazio: ensaio sobre o individualismo contemporâneo. Lisboa: Antropos, 1989.

LYOTARD, J.-F. A condição pós-moderna. Lisboa: Gradiva, 1985.

MATTÉI, J.-F. A barbárie interior. São Paulo: UNEsP, 2002.

POCHMANN, M. A exclusão social no mundo. São Paulo: Cortez, 2004.

RAWLS, J. Teoria da justiça. Lisboa: Presença, 1993.

ROUSSEAU, J.-J.. Emilio ou da educação. São Paulo: Bertrand Brasil, 1992.

ROUSSEAU, J.-J. Do contrato social. São Paulo: Martin Claret, 2007.

VATTIMO, G. O fim da modernidade: nihilismo e hermenêutica na cultura pós-moderna. São Paulo: Martins Fontes 1996.

WEBER, M. Ciência e politica: duas vocações. São Paulo: Martin Claret, 2005. 